性がある.リンの社会関倸資本を分析視角とする検討もイギリスについては終章で 少し述べられている程度であるが，ミクロな観点も含め，イギリスの若者支援政策 に扔ける社会関倸資本のあり方についての検討がもう少し明確になされるとよりよ い比較研究となろう. 今後のさらなる研究に期待している.

\title{
櫻井義秀 編
}

\section{『宗教とウェルビーイング——しあせの宗教社会学』}

(北海道大学出版会, A5 判, 438 頁, 5,800 円 +税)

高橋 典史

(東洋大学社会学部教授)

本書は, 近年進展しつつある「ウェルビーイング」の領域に宗教社会学からアプ ローチした論集である．本書によれば，これまで社会学においては，人びとの「不 幸」の原因と見なされる社会的要因を解決・改善するための, 福祉制度や社会的支 援に関わる研究と実践に関心が寄せられてきたという. 他方, 宗教研究では, 世俗 の生活世界よりも宗教的な深みや境地における「幸福」に注目してきたとされる.

双方とも人びとの「幸福」に密接に関わるものであることは間違いない，しかし， 宗教社会学を専門とする執筆者たちが，人びとの日常生活と地続きのウェルビーイ ングのあり方と宗教との関倸性について，量的㧍よび質的な研究手法にもとづいて 多角的に論じている点が，本書の革新性である，そして，人びとのウェルビーイン グと宗教を理論的に架橋するものとして，ソーシャル・キャピタル論が用いられて いる，その背景には，編者の櫻井義秀たちがこれまで劧引してきた「宗教とソーシ ヤル・キャピタル」研究が提出してきた，宗教が豊かなソーシャル・キャピタルを 醸成することにより，人びとのウェルビーイングを高めうるという知見がある。そ れゆえ，本書はソーシャル・キャピタルとしての役割を果たしうる宗教と人びとの 幸福度の相関性についての検証を，実証研究の成果にもとづいて試みたものである といえる，以下，本書の内容を簡潔に紹介したい。

第 I 部は，宗教とウェルビーイングに関する理論的検討を行うパートである．第 1 章（櫻井義秀）は，宗教とウェルビーイングヤソーシャル・キャピタルについて 研究するうえでの諸議論の整理を行ったものである．第 2 章（櫻井義秀）では，ル ート・ヴェーンホヴェンのウェルビーイングの類型論などを参考にして, 宗教が人 びとの社会または生活環境・生活満足度・生きる力・幸福感に与えうる影響につい て整理されている，第 3 章（寺戸淳子）は，知的障害者と支援者たちが共同生活を 送る「ラルシュ共同体運動」の創始者の思想や近年のケア論の検討を通じて, 人び とが支え合う社会関係を成り立たせるものを理論的に論じたものである. 
第 II 部には，アジア，ヨーロッパ，日本における「宗教とウェルビーイング」に 関連する統計分析を試みた諸論考が並んでいる，第 4 章（真鍋一史）は, 宗教に焦 点を当てたものではないものの, 国際比較調査の「アジア・バロメーター」のデー 夕から各国における主観的幸福感と社会経済的指標との関連性を検証している. 第 5 章（ウォルフガング・ヤゴチンスキー）においては, 「ヨーロッパ社会調査」の データを使用して, 人びとの「宗教性」と幸福度との相関性についての諸仮説の検 証がなされている，第 6 章（櫻井義秀・清水香基）は, 櫻井らが 2017 年に実施し た総合的社会調查のデータをもとに, 慣習的宗教・制度的宗教・スピリチュアルに 関わる意識や諸実践と人びとの主観的幸福度の相関性が考察されている.

第正部には，日本と韓国に関する5つの事例研究の成果が収録されている．第 7 章 (猪瀬優理) においては, 水子供養の宗教的儀礼の実践についての諸議論を整理 したうえで，妊娠喪失という悲嘆（グリーフ）によるウェルビーイングの損失から の回復に関与する宗教がはらむ諸問題が論じられている. 第 8 章 (片桐資津子) で は, 高齢女性たちのライフヒストリー分析を通じて, 女性たちの主観的幸福感の形 成への宗教文化の影響が指摘されている. 第 9 章 (冬月律) は, いわゆる限界集落 において, 祭礼を通じたソーシャル・キャピタルが維持され, 地域の人びとの主観 的幸福感を支えている事例の紹介である，第 10 章（川又俊則）においては，人口 減少が進む地域社会において「衰退・消滅」の危機に直面しているキリスト教会の 事例を取り上げて, 教会の存続と信仰の維持のために「支え合う」ことが信者たち のウェルビーイングにつながっていることが指摘されている．第 11 章 (李賢京) は, 移民の増加により急速に多文化化が進行してきた韓国において, キリスト教団 体がさまざま支援活動を通じて, どのように移民たちのウェルビーイングに貢献し ているのかを報告している.

本書に収録されている諸論考はいずれも, 一読に值する. とはいえ, 最も学術的 な意義が高いのは，世界各国の「宗教とウェルビーイング」のありようを計量的に 検討した第 II 部であろう. 日常生活で抱く主観的幸福感と宗教との関係性は単純な ものではなく, 日本におけるスピリチュアルな宗教意識や実践と主観的幸福感の負 の相関関係や，ヨーロッパにおける宗教参加をともなわない宗教性の影響力など, 注目に值する論点が数多い. 今後, 第II 部の成果を踏まえた事例研究が展開される ことが期待される. 